\title{
Study of phosphorus adsorption and its relationship with soil properties, analyzed with Langmuir and Freundlich models
}

\author{
Fisseha Hadgu ${ }^{1,}$, , Heluf Gebrekidan ${ }^{1}$, Kibebew Kibret ${ }^{1}$, BirruYitaferu ${ }^{2}$ \\ ${ }^{1}$ School of Natural Resource Management and Environmental Science, Haramaya University, Haramaya, Ethiopia \\ ${ }^{2}$ Amhara Regional Agricultural Research Institute, Amhara National Regional State, Ethiopia
}

Email address:

habenfhb@gmail.com (Fisseha H.), helufgebrekidan@yahoo.com (Heluf G.), kibebewkibrett @yahoo.com (Kibebew K.), birru_yitaferu2002@yahoo.com (Birru Y.)

\section{To cite this article:}

Fisseha Hadgu, Heluf Gebrekidan, Kibebew Kibret, BirruYitaferu. Study of Phosphorus Adsorption and Its Relationship with Soil Properties, Analyzed with Langmuir and Freundlich Models. Agriculture, Forestry and Fisheries. Vol. 3, No. 1, 2014 , pp. 40-51. doi: 10.11648/j.aff.20140301.18

\begin{abstract}
Phosphorus (P) adsorption capacity and its relationship with some properties of five different soil types (Fluvisols, Cambisols, Vertisols, Arenosols and Nitosols) of Tigray Region, northern Ethiopia were studied during the main cropping season in 2012. Besides, fractionation of the total soil P in to Ca-P, Fe-P and Al-P was carried out and their relationships with $\mathrm{P}$ adsorption characteristics of the soil type under study were also studied. Adsorption data for the different soil types were obtained by equilibrating the respective soil samples for 24 hours at room temperature with $25 \mathrm{ml}$ of $0.01 \mathrm{M}$ $\mathrm{CaCl}_{2}$, containing $0,60,120,180,240,300,360,420,480$ and $540 \mathrm{mg} \mathrm{kg}^{-1}$ of applied external $\mathrm{P}$ as $\mathrm{KH}_{2} \mathrm{PO}_{4}$. The results of this study showed that Ca-P was highest followed by Fe-P in all the soils except in the Arenosols. Testing the Langmuir and Freundlich adsorption isotherms both showed well fitted with the correlation coefficients (r) that ranged from 0.951 to 0.999 in all the soils. Comparing the two adsorption models, the Freundlich model was slightly better in Vertisols, Arenosols and Nitosols while the Langmuir model was better in the Fluvisols and Cambisols in predicting P adsorption. The adsorption maximum (b) obtained from the Langmuir isotherm ranged from $296.6 \mathrm{mg} \mathrm{P} \mathrm{kg}{ }^{-1}$ soil in Fluvisols to $820.4 \mathrm{mg} \mathrm{P} \mathrm{kg}^{-1}$ soil in Vertisols. The constant related to bonding energy calculated from the Langmuir adsorption model varied from 0.0151 to $0.0447 \mathrm{~L} \mathrm{mg}^{-1}$. The Freundlich adsorption parameters also ranged from 7.28 to $30.15 \mathrm{mg} \mathrm{kg}^{-1}$ for the Freundlich isotherm constant $\left(\mathrm{K}_{\mathrm{f}}\right)$ and from 0.4874 to 1.012 for slope of the Freundlich isotherm $(1 / \mathrm{n})$. Among the soil properties $\left(\mathrm{CaCO}_{3}, \mathrm{CEC}\right.$, organic matter, $\mathrm{EC}, \mathrm{pH}$, and sand, silt, and clay contents), clay content, $\mathrm{CEC}$ and $\mathrm{CaCO}_{3}$ were positively correlated with the Langmuir adsorption maximum. The adsorption maximum significantly $(\mathrm{P} \leq 0.05)$ correlated $(\mathrm{r}=-0.902$ but decreased with increasing sand content. The constant $\left(\mathrm{K}_{\mathrm{f}}\right)$ positively and significantly $(\mathrm{P} \leq 0.05)$ correlated $(\mathrm{r}=0.953)$ with $\mathrm{EC}$ of the soil. The remaining soil properties studied were not significantly correlated with the adsorption parameters.
\end{abstract}

Keywords: Phosphorus Content, Isotherms, Freundlich Model, Langmuir Model, Soil Characterization, Ethiopian Soils

\section{Introduction}

Adsorption which is the net accumulation of chemical species at the interface between a solid phase and an aqueous solution phase determine availability of native soil $\mathrm{P}$ and the rate of $\mathrm{P}$ applied to soils in fertilizers. When soluble $\mathrm{P}$ compounds are added to the soil, they undergo a series of complex reactions which lead to the decline of the availability of the added P. The compounds react rapidly with soil minerals by precipitation reactions and adsorption onto the soil's solid particle surfaces. Adsorption reaction is one of the principal processes involved in the retention of $\mathrm{P}$ (1).

The physico-chemical characteristics of soils largely influence the parameters of adsorption process and this eventually governs the availability of nutrient ions to the growing plants. Among the soil properties affecting the $\mathrm{P}$ adsorption capacity are soil texture (2), organic matter content (3), soil pH (4) and $\mathrm{CaCO}_{3}$ content (5) of the soil. The surface charge of clay minerals (and oxides) is partly $\mathrm{pH}$ 
dependent, so that anion exchange capacity increases as $\mathrm{pH}$ decreases (6). According to (6) possible major factors affecting $\mathrm{P}$ adsorption of soils can be ascribed as physicochemical properties of soils such as clay type and clay content. They reported higher $\mathrm{P}$ adsorption by Entisols which had satisfactory level of organic matter and medium level available $P$ than that of other soils in Sudan.

In addition to adsorption, the release of $\mathrm{P}$ through natural processes is very scanty, whereas the sinks for $\mathrm{P}$ especially at the ground of ocean are huge (7). Therefore the amount of $P$ in soil solution is low. Phosphorus deficiency in crop plants is therefore a widespread nutritional disorder. Its deficiency in soils usually occur due to too low concentration of orthophosphate in the soil solution rather than from inadequate total $\mathrm{P}$ content which is partly due to $\mathrm{P}$ adsorption in the soil. Many researchers have established that $\mathrm{P}$ is essential in plants in energy transfer, being constituent part of adenosine Tri phosphate. Phosphorus is required particularly by the growing tips of plants, hence its importance for root growth. Any shortage, especially in the very early stages, reduces root growth and nutrient uptake and this can adversely affect the growth of crops for the rest of a growing season. Phosphorus fertilization and its management is a means of improving soil $\mathrm{P}$ for crop production in the cropping system. Better management of $\mathrm{P}$ fertilizer can be achieved by studying the $\mathrm{P}$ adsorption behavior of the soil. Phosphorus adsorption curve helps in predicting the fertilizer $\mathrm{P}$ needed to replenish the soil solution P to a level optimum for a particular crop (8). The Langmuir adsorption equation was popular among soil chemists for monitoring $\mathrm{P}$ adsorption and calculating the crop $\mathrm{P}$ requirements since 1957. The Freundlich and Langmuir adsorption isotherms are usually used to describe adsorption of different compounds by soils.

The Ethiopian soils, similar to the other agricultural soils of the tropics, are generally low in available P. Several authors have reported independently that $70-75 \%$ of some Ethiopian agricultural soils are deficient in plant available $\mathrm{P}$ (9, 10 and 11). In Tigray, northern Ethiopia, most of the farmers usually apply $\mathrm{P}$ fertilizers without judging the $\mathrm{P}$ status of the soils for which $\mathrm{P}$ adsorption study have significant role to play. Fluvisols, Cambisols, Arenosols, Vertisols and Nitosols are the common types of soils in the whole Tigray as well as in the study areas. Vertisols in Adigudom, Adwa, Wukro, Shire and Michew areas of Tigray Regional National State are low in $\mathrm{P}$ and micronutrients (12). Many local experimental results also indicated that these soils are low in these plant nutrients. However, very little detailed work has been done on the $\mathrm{P}$ adsorption of Ethiopian soils $(13 ; 14 ; 15$ and 11) in general and no $\mathrm{P}$ adsorption study has been conducted in Tigray in particular and most of the studies conducted in Ethiopia as well as in the Region so far on these soils have mainly been on fertilizer experiments. The objectives of this study were therefore to quantify $\mathrm{P}$ adsorption capacity, bonding energy and other adsorption parameters of the Langmuir and Freundlich models on major soils; to examine the relationship of these adsorption parameters with dominant soil properties and to determine the contents of different forms of P (Ca-P, Fe-P and Al-P) and correlate these forms with adsorption parameters.

\section{Materials and Methods}

\subsection{Description of the Study Area}

The study was conducted in 2012 at the soil laboratory of the Mekelle Agricultural Research Center, northern Ethiopia Representative soil samples including Fluvisols from Birki site (latitude $13^{\circ} 42^{\prime} \mathrm{N}$; longitude $39^{\circ} 39^{\prime} \mathrm{E}$ and altitude of 2065 masl); Cambisols from Agulae site (latitude $13^{\circ} 41^{\prime} \mathrm{N}$; longitude: $39^{\circ} 35^{\prime} \mathrm{E}$ and altitude 1991 masl); Vertisols from Wukro (latitude $13^{\circ} 45^{\prime} \mathrm{N}$; longitude $39^{\circ} 36^{\prime} \mathrm{E}$ and altitude 1988 masl); Arenosols from Wukro (latitude $13^{\circ} 48^{\prime} \mathrm{N}$; longitude: $39^{\circ} 35^{\prime} \mathrm{E}$ and altitude 1986 masl) in Eastern Zone and Nitosols from Mailaham (latitude 14 ${ }^{\circ} 9^{\prime} 16^{\prime \prime}$; $\mathrm{N}$ :longitude $38^{\circ} 18^{\prime} 10^{\prime \prime} \mathrm{E}$ and altitude 1940 masl) in North Western Zone of Tigray National Regional State were collected for this study. The four soil samples were classified as Eutric Fluvisols (Agulae series), Eutric Cambisols (Agulae series), chromic Vertisols (Gormodo series) and Cambic Arenosols (Abraha series) by (16). All the soils are found in semi-arid agro-ecology of Tigray. The topography of the Tigray Region including the surrounding of the sampling sites is mainly the extension of the central highlands which comprises mountains, highland plateaus and gorges. The samples were collected from flat terrain with slopes seldom exceeding $2 \%$, representing farms supplemented by irrigation. According to (17), the mean rainfall for the District of Wukro in eastern Tigray (the nearest place with meteorological data for Eastern Zone soil sampling sites) for the years 1963 to 1997 was $650 \mathrm{~mm}$. The mean annual rainfall for the four sampling sites from Birki, Agulae and Wukro areas is about $590 \mathrm{~mm}$ and the maximum and minimum temperatures range from 23-28 and from 9-14 ${ }^{\circ} \mathrm{C}$, respectively (National Meteorological Service Agency, Wukro Station). The mean annual rainfall for the Nitosols which is located in Shire area is $987 \mathrm{~mm}$ having five months LGP (length of growing period) which is longer than the LGP at Wukro that has three months (12).

\subsection{Soil Sampling and Characterization}

Surface soil samples from five soil types, which were selected based on preliminary survey as well as on secondary information, were collected from 20 sub sampling sites per composite sample at a depth of $0-15 \mathrm{~cm}$ using auger before sowing. The composite soil samples for the laboratory analysis were air dried, crushed using pestle and mortar and passed through a $2 \mathrm{~mm}$ diameter sieve for analysis of most of the soil chemical properties. A portion of the disturbed soil sample was taken and sieved using $0.5 \mathrm{~mm}$ diameter for the determinations of organic matter.

One composite sample was prepared by mixing the different soil subsamples for the laboratory analyses of soil 
properties, $\mathrm{P}$ adsorption and iron $(\mathrm{Fe})$, calcium $(\mathrm{Ca})$ and aluminium (Al) $\mathrm{P}$ as well as for determination of soil texture. The samples were transported to Mekelle for laboratory analysis.

Particle size distribution was determined by the hydrometer method (18). Once the sand, silt, and clay separates were calculated in percent, the soil was assigned to a textural class based on the soil textural triangle using International Soil Science Society (ISSS) system (19).

Soil $\mathrm{pH}$ in water was determined by the glass electrode $\mathrm{pH}$ meter (20) at 1:2.5 soils to water ratios. The electrical conductivity (EC) of the soils was measured according to the method described by (20). The cation exchange capacity (CEC) was determined by the method described by (21). Exchangeable potassium (K) and Exchangeable sodium (Na) were determined using flame photometer as described by (22), while calcium (Ca) and magnesium ( $\mathrm{Mg}$ ) were determined by atomic absorption spectrophotometer method (23). Percent base saturation (PBS) was calculated from exchangeable $\mathrm{K}$ ion, $\mathrm{Ca}$ ion, $\mathrm{Mg}$ ion, $\mathrm{Na}$ ion and $\mathrm{CEC}$. Calcium carbonate $\left(\mathrm{CaCO}_{3}\right)$ was determined by titration according to (24). Soil available $\mathrm{P}$ was analyzed using Olsen method (39) modified by (25). To determine organic carbon, the (26) method was employed. Finally, the organic matter content of the soil was calculated by multiplying the organic carbon percentage by 1.724 .

Inorganic $\mathrm{P}$ was fractionated by the method of (27) as modified by (28) to obtain Fe-P, Al-P and Ca-P contents of the soils. Phosphorus in the soil was determined colorimetrically by the molybdenum blue color method of (29).

\subsection{Phosphorus Adsorption Studies}

Phosphorus adsorption was studied using the method of (30). A duplicate of $3 \mathrm{~g}$ portion of each soil sample containing levels of $0,60,120,180,240,300,360,420,480$ and $540 \mathrm{mg} \mathrm{P} \mathrm{kg}^{-1}$ as $\mathrm{KH}_{2} \mathrm{PO}_{4}$ in $25 \mathrm{ml}$ of $0.01 \mathrm{M} \mathrm{CaCl}_{2}$ was shaken on an end-to-end shaker at 150 oscillations per minute for 24 hours at room temperature. After equilibrium achieved, sod solution was centrifuged in 50-ml centrifuge tube for 10 minutes at 3000 revolution per minute and the supernatant was decanted. The decanted part then was filtrated with a filter paper (Whatman number 40). Phosphorus in equilibrium solution was determined by Olsen method.

Amount of $\mathrm{P}$ adsorbed by the soils was determined by the difference between initial and final amounts of $\mathrm{P}$ concentrations in the equilibrium solution. The data were used to fit the linearized Langmuir and Freundlich equations, hence to determine the model parameters; and for model validation. The Freundlich and Langmuir models were used to describe $\mathrm{P}$ adsorption:

Langmuir equation:

$\{\mathrm{C} /(\mathrm{x} / \mathrm{m})\}=1 / \mathrm{Kb}+\mathrm{C} / \mathrm{b}$

Where, $\mathrm{C}=$ Concentration of $\mathrm{P}$ in soil solution at equilibrium ( $\left.\mathrm{mg} \mathrm{P} \mathrm{L}^{-1}\right), \mathrm{x} / \mathrm{m}=$ Amount of $\mathrm{P}$ adsorbed $(\mathrm{mg}$ $\mathrm{kg}^{-1}$ soil), $\mathrm{b}=$ Adsorption maximum ( $\mathrm{mg} \mathrm{P} \mathrm{kg}^{-1}$ soil), $1 / \mathrm{K} \mathrm{b}=$

$\mathrm{Y}$ - Intercept and $\mathrm{K}=$ Constant, i.e. adsorption affinity ( $\mathrm{L}$ $\left.\mathrm{mg}^{-1} \mathrm{P}\right)$.

Freundlich equation:

$\mathrm{x} / \mathrm{m}=\mathrm{K}_{\mathrm{f}} \mathrm{C}^{1 / \mathrm{n}}$

Where, $\mathrm{x} / \mathrm{m}=\mathrm{P}$ adsorbed $\left(\mathrm{mg} \mathrm{P} \mathrm{kg}^{-1}\right.$ soil $), \mathrm{C}=$ Concentration in soil solution at equilibrium $\left(\mathrm{mg} \mathrm{P} \mathrm{L}^{-1}\right), \mathrm{K}_{\mathrm{f}}=$ Proportionality constant for Freundlich equation, $1 / \mathrm{n}=$ Slope of the curve $(\log \mathrm{C}$ vs. $\log \mathrm{x} / \mathrm{m})$ and $\log \mathrm{K}_{\mathrm{f}}=\mathrm{Y}$ intercept.

\subsection{Data Analysis}

Regression techniques were used for model validation and to determine the functional relationship between the model parameters and selected soil properties including $\mathrm{P}$ adsorption maximum (b) values with soil properties including percent sand silt and clay, $\mathrm{pH}, \mathrm{EC}, \mathrm{CaCO}_{3}$, organic matter content, $\mathrm{CEC}$ as well as Fe-P, Ca-P and Al-P contents. In addition,. Mean square error (MSE) and correlation coefficients were used to compare the performance of two parameterized adsorption isotherms.

\section{Results and Discussion}

\subsection{Soil Properties}

Soils of the study sites varied in texture and chemical characteristics. Some important soil properties are presented in Table 1. The textural classes of the soils under investigation are sandy loam for the Fluvisols, Cambisols and Arenosols, whereas it is clay for the Vertisols and Nitosols based on the soil textural triangle of the ISSS system (19). As per rating suggested by (31), the soil organic matter content was very low for Nitosols, low for the Fluvisols and Arenosols and moderate for Cambisols and Vertisols. The very low amount of organic matter in Shire area may be due to its faster decomposition because of high temperature of the area. The data further revealed that the Arenosols and Nitosols soil samples were neutral and the Fluvisols, Cambisols and Vertisols were mildly alkaline. On the basis of EC limit purposed by (32), the soils under investigation fall in the category of very low EC for Arenosols and Nitosols, low for the Fluvisols, medium for Vertisols and high for Cambisols. The Fluvisols and Arenosols have low; Cambisols and Nitosols had moderate and Vertisols had high CEC values, on the basis of CEC rating by (33). As per rating of (34) $\mathrm{CaCO}_{3}$ content was moderate in all the soils. The PBS calculated from these cations was moderate for the Nitosols, high for the Arenosols and very high for the other three soils according to rating by (33). Based on the rating set by (35), the available phosphorus in the plow layer of all the soils is found low (Table 1). 
Table 1. Physical and chemical properties of Fluvisols, Cambisols, Vertisols, Arenosols and Nitosols in the study areas

\begin{tabular}{|c|c|c|c|c|c|}
\hline Soil property* & Fluvisols & Cambisols & Vertisols & Arenosols & Nitosols \\
\hline Sand $(\%)$ & 74 & 69 & 42 & 75 & 32 \\
\hline Silt (\%) & 16 & 17 & 12 & 5 & 26 \\
\hline Clay $(\%)$ & 10 & 14 & 46 & 20 & 42 \\
\hline Textural class & SL & SL & Clay & SL & Clay \\
\hline pH 1:2.5 $\left(\mathrm{H}_{2} \mathrm{O}\right)$ & 7.50 & 7.60 & 7.70 & 7.00 & 6.70 \\
\hline $\mathrm{EC}\left(\mathrm{dS} \mathrm{m}{ }^{-1}\right)$ & 0.11 & 0.62 & 0.18 & 0.05 & 0.04 \\
\hline $\mathrm{CaCO}_{3}(\%)$ & 6.0 & 7.5 & 9.0 & 7.0 & 8.0 \\
\hline OM $(\%)$ & 1.30 & 2.63 & 2.35 & 1.32 & 0.94 \\
\hline Available P (mg kg $\left.{ }^{-1}\right)$ & 5.00 & 11.00 & 3.60 & 3.60 & 5.80 \\
\hline Exchangeable $\mathrm{Ca}\left(\mathrm{cmol}(+) \mathrm{kg}^{-1}\right)$ & 5.90 & 12.40 & 11.40 & 6.90 & 8.10 \\
\hline Exchangeable $\mathrm{Mg}\left(\mathrm{cmol}(+) \mathrm{kg}^{-1}\right)$ & 1.00 & 1.90 & 8.20 & 0.90 & 1.20 \\
\hline Exchangeable $\mathrm{Na}\left(\mathrm{cmol}(+) \mathrm{kg}^{-1}\right)$ & 0.24 & 0.10 & 0.20 & 0.10 & 0.13 \\
\hline Exchangeable $\mathrm{K}\left(\mathrm{cmol}(+) \mathrm{kg}^{-1}\right)$ & 0.82 & 0.86 & 0.90 & 0.70 & 0.79 \\
\hline $\mathrm{CEC}\left(\operatorname{cmol}(+) \mathrm{kg}^{-1}\right)$ & 8.80 & 17.40 & 22.80 & 11.00 & 20.80 \\
\hline Base saturation (\%) & 90.45 & 87.90 & 90.80 & 86.55 & 63.03 \\
\hline
\end{tabular}

$\mathrm{OM}=$ Organic matter, $\mathrm{CEC}=$ Cation exchange capacity, $\mathrm{SL}=$ Sandy loam.

\subsection{Relationship between Soil Properties and P Adsorption Parameters}

In all the soils, $\mathrm{P}$ adsorption characteristics were influenced by some soil characteristics at varying levels. Adsorption maximum was significantly ( $\mathrm{P} \leq 0.01$ for clay and $\mathrm{P} \leq 0.05$ for $\mathrm{CaCO} 3$ and $\mathrm{CEC})$ and positively correlated with clay $(\mathrm{r}=0.975), \mathrm{CaCO} 3(\mathrm{r}=0.912)$ and $\mathrm{CEC}(\mathrm{r}=0.885)$ (Table 2). Sand content was significantly $(\mathrm{P} \leq 0.05)$ and negatively correlated $(\mathrm{r}=-0.902)$ with Langmuir adsorption maxima (b). No significant correlations were observed between Langmuir adsorption parameters and the other soil characteristics studied (Table 2). According to (36), most soil properties used in predicting soil $\mathrm{P}$ are interrelated and this makes it difficult to identify the principal components contributing to P-availability in soils. Multiple correlation coefficient of $\mathrm{K}$ with both clay and $\mathrm{CaCO} 3$ contents was also non significant $(\mathrm{R} 2=0.6179)$. Similarly $(37)$ reported that clay contents were major contributors to $\mathrm{P}$ adsorption in Australian soils. The positive relationship of $\mathrm{P}$ adsorption with clay content and negative correlation with sand content may be related with larger surface area of clay as compared to sand. It could also be related to the relatively large number of positive charges that can react and strongly bind the negatively charged phosphate ions in soil solution. A negative non significant correlation was observed between the soil Olsen-P and $\mathrm{P}$ adsorption maxima (Table 2). According to (38) a positive correlation between soil Olsen-P and soil $\mathrm{P}$ adsorption was found in Iran. No significant correlations were observed between Langmuir parameters and soil organic matter (Table 2). Phosphorus adsorption at low concentrations of added $\mathrm{P}$ negatively correlates with organic carbon suggesting that organic matter may compete with P for adsorption sites. (39) and (40) showed that coefficient for soil OM to predict maximum $P$ adsorption had positive sign and the soils with high $\mathrm{OM}$ had poorly crystalline iron oxides suggesting inhibiting effect on iron oxide crystallization through complexation increasing sorption capacity for phosphate.

Table 2 Correlation between Langmuir adsorption parameters and selected soil characteristics of the five soils in the study areas

\begin{tabular}{|c|c|c|c|}
\hline $\begin{array}{c}\text { Soil property vs. Langmuir } \\
\text { adsorption parameter* }\end{array}$ & Regression equation & $\begin{array}{c}\text { Correlation } \\
\text { coefficient(r) }\end{array}$ & $\begin{array}{c}\text { Coefficient of determination } \\
\left(\mathbf{R}^{2}\right)\end{array}$ \\
\hline Sand vs. b & $\mathrm{b}=1184.44-10.21($ sand $)$ & $-0.902 *$ & 0.8136 \\
\hline Silt vs. b & $\mathrm{b}=475.21+7.38$ (silt) & 0.245 & 0.0600 \\
\hline Clay vs. b & $\mathrm{b}=234.78+13.35$ (clay) & $0.975 * *$ & 0.8084 \\
\hline pH vs. b & $\mathrm{b}=1757.19-160.26(\mathrm{pH})$ & -0.305 & 0.0929 \\
\hline $\mathrm{CaCO}_{3}$ vs. b & $\mathrm{b}=-798.98+184.44\left(\mathrm{CaCO}_{3}\right)$ & $0.912 *$ & 0.8316 \\
\hline CEC vs. b & $\mathrm{b}=81.17+31.63$ CEC) & $0.885^{*}$ & 0.7840 \\
\hline EC vs. $b$ & $\mathrm{~b}=634.82-237.45(\mathrm{EC})$ & -0.254 & 0.0643 \\
\hline OM vs. b & $\mathrm{b}=579.85+4.37 \quad(\mathrm{OM})$ & 0.014 & 0.0002 \\
\hline Olsen-P & $\mathrm{b}=707.2-20.67($ Olsen-P) & -0.279 & 0.0781 \\
\hline Sand vs. K & $\mathrm{K}=0.0008+0.0004(\mathrm{sand})$ & 0.668 & 0.4457 \\
\hline Silt vs. K & $\mathrm{K}=0.025-00005$ (silt) & -0.015 & 0.0002 \\
\hline
\end{tabular}




\begin{tabular}{llcc}
\hline \multicolumn{1}{c}{$\begin{array}{c}\text { Soil property vs. Langmuir } \\
\text { adsorption parameter* }\end{array}$} & \multicolumn{1}{c}{ Regression equation } & $\begin{array}{c}\text { Correlation } \\
\text { coefficient(r) }\end{array}$ & $\begin{array}{c}\text { Coefficient of determination } \\
\left(\mathbf{R}^{2}\right)\end{array}$ \\
\hline Clay vs. $\mathrm{K}$ & $\mathrm{K}=0.0399-0.0006$ (clay) & -0.804 & 0.6408 \\
pH vs. $\mathrm{K}$ & $\mathrm{K}=-0.044+0094(\mathrm{pH})$ & 0.033 & 0.1110 \\
$\mathrm{CaCO}_{3}$ vs. $\mathrm{K}$ & $\mathrm{K}=-0.0946-0.0094\left(\mathrm{CaCO}_{3}\right)$ & -0.864 & 0.7426 \\
$\mathrm{CEC}$ vs. $\mathrm{K}$ & $\mathrm{K}=0.0 .0490-0.0015(\mathrm{CEC})$ & -0.803 & 0.6449 \\
$\mathrm{EC}$ vs. $\mathrm{K}$ & $\mathrm{K}=0.0237-0.0035(\mathrm{EC})$ & 0.070 & 0.0001 \\
OM vs. $\mathrm{K}$ & $\mathrm{K}=0.0284-0.0024(\mathrm{OM})$ & -0.143 & 0.0001 \\
\hline
\end{tabular}

$* *=$ Significantly correlated at $\mathrm{P}=0.01 ; *=$ significantly correlated at $\mathrm{P}=0.05 ; \mathrm{CEC}=$ Cation exchange capacity; EC $=$ Electrical conductivity; $\mathrm{b}=$ Langmuir adsorption maximum; $\mathrm{K}=$ Langmuir constant related to bonding energy; $\mathrm{OM}=$ Organic matter.

No significant correlations were observed between Langmuir adsorption parameters and soil organic matter (Table 2). (41) also reported that $\mathrm{P}$ adsorption was significantly correlated with clay and CEC. Positive and negative relationships of organic matter and $\mathrm{P}$ adsorption had also been reported by several researchers. (42) recorded on highly weathered soils that the presence of organic matter reduces $\mathrm{P}$ adsorption capacity due to direct result of competition for adsorption sites between phosphate and organic ligands. There was also suggestion that the possibility of organic matter to reduce positive charge on variable charge surfaces by lowering $\mathrm{pH}$ (7) and this decreases the attraction of $\mathrm{P}$ to the soil surface. On the contrary, positive relationships between the organic matter contents of soils and P adsorption was reported (43). They found that the role of organic matter in increasing the ability of soils to adsorb $\mathrm{P}$ that is attributed to its association with cations such as $\mathrm{Fe}, \mathrm{Al}$ and $\mathrm{Ca}$.

\subsection{Phosphorus Fractionation}

Table 3. Phosphorus contents in the form of Al-P, Ca-P and Fe-P of the soils

\begin{tabular}{llll}
\hline Soil type & $\mathbf{A l}-\mathbf{P}\left(\mathbf{m g ~ k g}^{-1}\right)$ & $\mathbf{F e}-\mathbf{P}\left(\mathbf{m g ~ k g}^{-1}\right)$ & $\mathbf{C a}-\mathbf{P}\left(\mathbf{m g ~ k g}^{-1}\right)$ \\
\hline Fluvisols & 28.6 & 90.0 & 300.0 \\
Cambisols & 31.6 & 120.0 & 410.0 \\
Vertisols & 21.7 & 165.0 & 320.0 \\
Arenosols & 8.3 & 385.0 & 310.0 \\
Nitosols & 10.0 & 375.0 & 530.0 \\
\hline
\end{tabular}

The amount of Ca-P was higher in all the soils except in the Arenosols in which Fe-P was higher compared to Ca-P and Al-P. This may be due to the location of the soils in semiarid agro-ecology in which $\mathrm{Ca}$ ion is not leached down from the upper soil layers to the subsurface soil horizons and reacts with $\mathrm{P}$ to form $\mathrm{Ca}-\mathrm{P}$. The $\mathrm{Fe}-\mathrm{P}$ was next to $\mathrm{Ca}-\mathrm{P}$ in all the other soils (Table 3 ). Similar results of $P$ fractionation on Vertisols in India reported by (44) showed that Ca-P was the dominant form followed by Fe-P with very low amount of Al-P.

\subsection{Langmuir and Freundlich Equations for the Studied Soils}

\subsubsection{Correlation between Adsorption Parameters}

Langmuir adsorption maximum (b) showed higher opposite correlation with Langmuir adsorption parameter $(\mathrm{K})$ but all other correlations were not significant (Table 4). Significant correlation between Langmuir adsorption maximum (b) and slope of the Freundlich model (1/n) makes calculation of the value of $\mathrm{P}$ adsorption maximum from the Freundlich model possible with the help of this relationship. It can help if the Freundlich model showed superiority over the Langmuir model because it is impossible to calculate adsorption maximum directly from the Freundlich model (45). However, no significant correlation was observed between $\mathrm{b}$ and $1 / \mathrm{n}$ in this study (Table 4$)$.

Significant $(\mathrm{P} \leq 0.05)$ correlation was observed between EC and $\mathrm{K}_{\mathrm{f}}$ of the Freundlich adsorption model. No significant correlation was observed between Freundlich adsorption parameters and other soil characteristics (Table 6). Multiple correlation coefficient of $1 / \mathrm{n}$ with both sand and clay contents was no significant $\left(\mathrm{R}^{2}=0.7045\right)$. Multiple correlation coefficient of $\mathrm{K}_{\mathrm{f}}$ with both $\mathrm{pH}$ and OM content was also non significant $\left(\mathrm{R}^{2}=0.6087\right)$.

Table 4 Correlation between the Langmuir and/or the Freundlich equation (s)

\begin{tabular}{cccc}
\hline Correlation between & Regression equation & Correlation Coefficient $(\mathbf{r})$ & Coefficient of Determination $\left(\mathbf{R}^{2}\right)$ \\
\hline $\mathrm{K}$ and $\mathrm{b}$ & $\mathrm{b}=10001.08-16943.5(\mathrm{~K})$ & $-0.907^{*}$ & 0.8226 \\
$\mathrm{~b}$ and $\mathrm{K}$ & $\mathrm{K}=0.0529-0.00049(\mathrm{~b})$ & $-0.907^{*}$ & 0.8226 \\
$\mathrm{~b}$ and $1 / \mathrm{n}$ & $1 / \mathrm{n}=0.4127+0.007(\mathrm{~b})$ & 0.728 & 0.5300 \\
$\mathrm{~b}$ and $\mathrm{K}_{\mathrm{f}}$ & $\mathrm{Kf}=24.74-0.0197(\mathrm{~b})$ & -0.461 & 0.2125 \\
$1 / \mathrm{n}$ and $\mathrm{b}$ & $\mathrm{b}=-35.56+755.45(1 / \mathrm{n})$ & 0.728 & 0.5300 \\
$\mathrm{~K}_{\mathrm{f}}$ and $\mathrm{b}$ & $\mathrm{b}=729.01-10.775\left(\mathrm{~K}_{\mathrm{f}}\right)$ & -0.461 & 0.2125 \\
\hline
\end{tabular}

*Correlation is significant at 0.05 level; $=\mathrm{b}=$ Langmuir adsorption maximum; $\mathrm{K}=$ Langmuir constant related to bonding energy; $\mathrm{K}_{\mathrm{f}}=$ Freundlich constant related to extent of adsorption; $1 / \mathrm{n}=$ Slope of the Freundlich isotherm. 
Table 5 Adsorption equations for Freundlich and Langmuir models for the five soils.

\begin{tabular}{|c|c|c|c|c|c|c|}
\hline Soil type & Freundlich model & Correlation coefficient ( $\mathbf{r}$ ) & LSE & Langmuir model & Correlation coefficient ( $\mathbf{r}$ ) & LSE \\
\hline Fluvisols & $\mathrm{x} / \mathrm{m}=11.72 \mathrm{C}^{0.7467}$ & $0.985 * *$ & 19.45 & $\mathrm{x} / \mathrm{m}=13.244 \mathrm{C} / 1+0.0447 \mathrm{C}$ & $0.987 * *$ & 14.39 \\
\hline Cambisols & $\mathrm{x} / \mathrm{m}=30.15 \mathrm{C}^{0.4874}$ & $0.994 * *$ & 75.14 & $\mathrm{x} / \mathrm{m}=12.114 \mathrm{C} / 1+0.0257 \mathrm{C}$ & $0.974 * *$ & 19.02 \\
\hline Vertisols & $\mathrm{x} / \mathrm{m}=7.29 \mathrm{C}^{1.0054}$ & $0.999 * *$ & 14.96 & $\mathrm{x} / \mathrm{m}=12.356 \mathrm{C} / 1+0.0151 \mathrm{C}$ & $0.951 * *$ & 32.37 \\
\hline Arenosols & $\mathrm{x} / \mathrm{m}=9.32 \mathrm{C}^{0.8707}$ & $0.999 * *$ & 5.83 & $\mathrm{x} / \mathrm{m}=11.109 \mathrm{C} / 1+0.0207 \mathrm{C}$ & $0.974 * *$ & 27.48 \\
\hline Nitosols & $\mathrm{x} / \mathrm{m}=7.28 \mathrm{C}^{1.0124}$ & $0.999 * *$ & 19.29 & $\mathrm{x} / \mathrm{m}=12.906 \mathrm{C} / 1+0.0159 \mathrm{C}$ & $0.982 * *$ & 32.09 \\
\hline Mean & - & $0.995 * *$ & & & $0.974 * *$ & \\
\hline
\end{tabular}

$* *=$ Correlation is significant ate 0.01 level, $\mathrm{n}=10 ; \mathrm{LSE}=$ Least significant error

Table 6 Correlation between Freundlich adsorption parameters and selected soil characteristics of the five soils in Tigray, northern Ethiopia

\begin{tabular}{llll}
\hline $\begin{array}{l}\text { Soil property vs. Freundlich adsorption } \\
\text { Parameter }\end{array}$ & Regression equation & Correlation coefficient(r) & $\begin{array}{c}\text { Coefficient of determination } \\
\left(\mathbf{R}^{2}\right)\end{array}$ \\
\hline Sand vs. $\mathrm{K}_{\mathrm{f}}$ & $\mathrm{K}_{\mathrm{f}}=0.5274+0.2161$ (sand) & 0.446 & 0.1989 \\
Silt vs. $\mathrm{K}_{\mathrm{f}}$ & $\mathrm{K}_{\mathrm{f}}=11.60+0.1021$ (silt) & 0.081 & 0.0066 \\
Clay vs. $\mathrm{K}_{\mathrm{f}}$ & $\mathrm{K}_{\mathrm{f}}=22.08-0.338(\mathrm{clay})$ & -0.578 & 0.3341 \\
pH vs. $\mathrm{K}_{\mathrm{f}}$ & $\mathrm{K}_{\mathrm{f}}=-57.33+9.65(\mathrm{pH})$ & 0.429 & 0.1840 \\
$\mathrm{CaCO}_{3}$ vs. $\mathrm{K}_{\mathrm{f}}$ & $\mathrm{K}_{\mathrm{f}}=24.64-1.53\left(\mathrm{CaCO}_{3}\right)$ & -0.177 & 0.0313 \\
$\mathrm{CEC}_{\text {vs. } \mathrm{K}_{\mathrm{f}}}$ & $\mathrm{k}_{\mathrm{f}}=14.51-0848(\mathrm{CEC})$ & -0.056 & 0.0031 \\
EC vs. $\mathrm{K}_{\mathrm{f}}$ & $\mathrm{K}_{\mathrm{f}}=5.51+38.20(\mathrm{EC})$ & 0.9082 \\
OM vs. $\mathrm{K}_{\mathrm{f}}$ & $\mathrm{K}_{\mathrm{f}}=-1.41+8.53(\mathrm{OM})$ & 0.649 & 0.4212 \\
Sand vs. $1 / \mathrm{n}$ & $1 / \mathrm{n}=1.26-0075(\mathrm{sand})$ & 0.686 & 0.4706 \\
Silt vs. $1 / \mathrm{n}$ & $1 / \mathrm{n}=0.8044+0.0013(\mathrm{silt})$ & 0.046 & 0.0021 \\
Clay vs. $1 / \mathrm{n}$ & $1 / \mathrm{n}=0.5430+0.0107(\mathrm{clay})$ & 0.809 & 0.6545 \\
pH vs. $1 / \mathrm{n}$ & $1 / \mathrm{n}=2.51-0.2310(\mathrm{pH})$ & -0.456 & 0.2080 \\
CaCO 3 vs. $1 / \mathrm{n}$ & $1 / \mathrm{n}=0.1362+0.0918(\mathrm{CaCO})$ & 0.471 & 0.2218 \\
CEC vs. $1 / \mathrm{n}$ & $1 / \mathrm{n}=0.6197+0.0128(\mathrm{CEC})$ & 0.372 & 0.1384 \\
EC vs. $1 / \mathrm{n}$ & $1 / \mathrm{n}=0.9749-0.7519(\mathrm{EC})$ & -0.833 & 0.6938 \\
OM vs. $1 / \mathrm{n}$ & $1 / \mathrm{n}=1.08+0.1450(\mathrm{OM})$ & -0.508 & 0.2581 \\
\hline
\end{tabular}

$*=$ Correlation is significant at $\mathrm{P}>0.05$ level; $\mathrm{CEC}=$ Cation exchange capacity; $\mathrm{EC}=$ Electrical conductivity; $\mathrm{b}=\mathrm{Langmuir}$ adsorption maximum; $\mathrm{K}=$ Langmuir constant related to bonding energy; $\mathrm{OM}=$ Organic matter; $1 / \mathrm{n}=$ Slope of the Freundlich isotherm.

\subsubsection{Model Validation}

The Langmuir and Freundlich generated equations are presented in Table 5 and graphs showing their validation are depicted in Figure 1 and 2. Generally, the choice between the models is often based on the goodness of fit (46). It is clear from Table 5 that both Freundlich and Langmuir models proved good based on average correlation coefficient values $(r=0.995$ for Freundlich and $(r=994$ for Langmuir ) in all the soils under investigation. On individual soil basis, the Langmuir model and Freundlich model were good but they have slight differences. Taking the correlation coefficient and least significant error (LSE) into account, Langmuir model was better in Fluvisols and Cambisols which were also lower in $\mathrm{P}$ adsorption capacity (Table 5). However, on Vertisols, Arenosols and Nitosols which were relatively higher in $\mathrm{P}$ adsorption, Freundlich model showed superiority over the Langmuir model on the basis of correlation coefficient and LSE values (Table 5). The least square error calculated for each soil indicated lower error by Langmuir equations than Freundlich on Fluvisols and Cambisols but Freundlich model showed lower least square error for Vertisols, Arenosols and Nitosols which showed similar but opposite trend to the correlation coefficient. Different results had been reported on the effectiveness of the two adsorption models in predicting $\mathrm{P}$ adsorption. (46) and (47) reported better results of the Langmuir model than the Freundlich model. (48) and (49) found that ability of the Freundlich model to describe $\mathrm{P}$ adsorption curves was superior to the Langmuir model for calcareous soils. However, (45) had reported comparable results for prediction of $\mathrm{P}$ adsorption by both the Langmuir and the Freundlich models. 




Figure 1 Validation for the Freundlich adsorption isotherm of the five soils

No significant $(\mathrm{P} \leq 0.05)$ correlation was observed between Langmuir and Freundlich adsorption parameters and Fe-P, Ca-P and Al-P of the soils. Multiple correlation

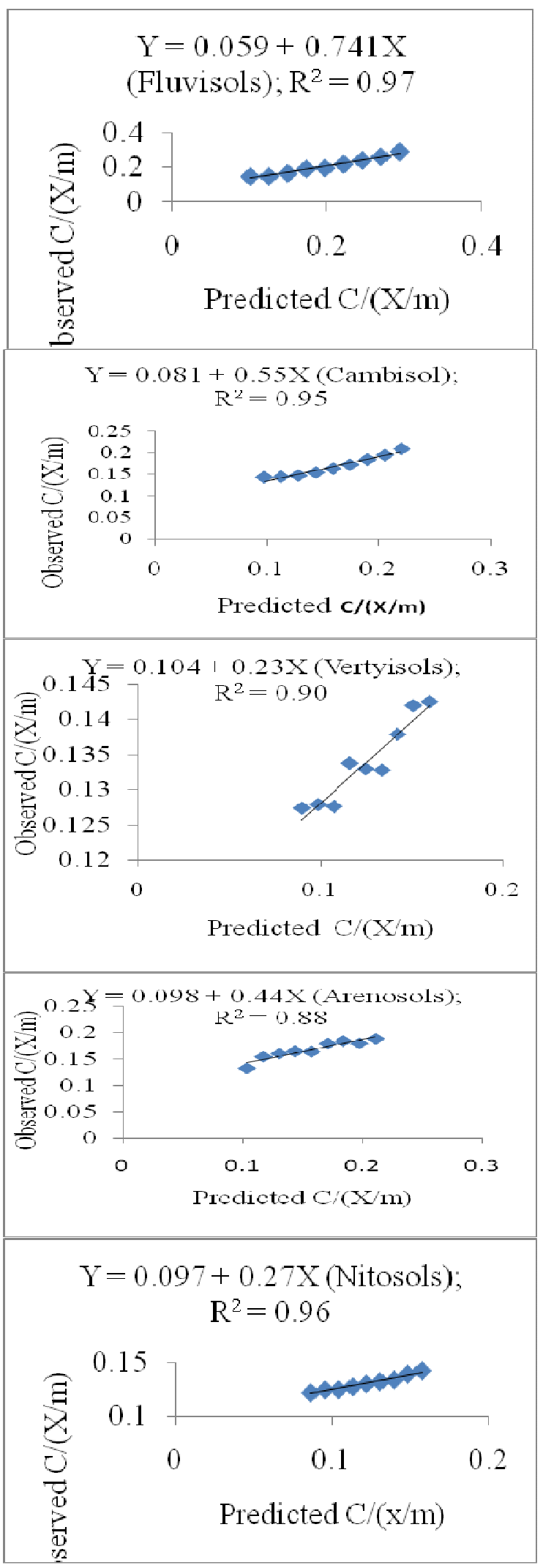

Figure 2. Validation for the Langmuir adsorption isotherm of the five soils.

coefficient of $\mathrm{b}$ with both $\mathrm{Ca}-\mathrm{P}$ and $\mathrm{Fe}-\mathrm{P}$ contents was also non significant $(\mathrm{P} \leq 0.05)$, $(\mathrm{R} 2=0.5542)$. However, Fe-P, $\mathrm{Ca}-\mathrm{P}$ and Al-P showed positive relations with most 
adsorption parameters (Table 7). Non significant $(\mathrm{P} \leq 0.05)$ correlation was obtained between Al-P and all adsorption parameters (Table 7). According to (50), hydrous iron and aluminium oxides and aluminosilicates react with phosphate solutions to produce an isomorphous series of iron and aluminium phosphates, the solubility criteria of which were believed to control the concentration of phosphate in the soil solution during 1950s. According to the report by (50), it is unlikely that the iron and aluminium phosphates persist for long to control dissolution and precipitation processes. They concluded that phosphate concentrations are largely independent of $\mathrm{pH}$ over the range of 4 to 8 and that the solution is invariably under saturated with resp.ect to all phosphate compounds. They stated based on studies done so far that iron and aluminum phosphates which were earlier assumed to occur in soil are more soluble than the corresponding metal oxides, which definitely do occur in soil and strongly adsorb phosphate ions. However, they stated that precipitation of calcium phosphates in soils above pH $6=$ can control the phosphate concentration in the soils. The present results of $\mathrm{P}$ fractionation of the studied soils coincide with their report with respect to Fe-P and Al-P except Fe-P with K and Kf; Ca-P with K and Al-P with b.

Table 7. Correlation between Al-P, Ca-P and Fe-P with adsorption parameters of both Langmuir and Freundlich

\begin{tabular}{llcc}
\hline $\begin{array}{l}\text { Soil P forms vs adsorption } \\
\text { parameter* }\end{array}$ & Regression equation & Correlation coefficient(r) & $\begin{array}{l}\text { Coefficient of determination } \\
\left(\mathbf{R}^{2}\right)\end{array}$ \\
\hline Fe-P vs. $b$ & $\mathrm{~b}=410.80+0.7775(\mathrm{Fe}-\mathrm{P})$ & 0.489 & 0.2392 \\
Ca-P vs. b & $\mathrm{b}=167.74+1.1219(\mathrm{Ca}-\mathrm{P})$ & 0.484 & 0.2346 \\
Al-P vs. $\mathrm{b}$ & $\mathrm{b}=815.09-11.37(\mathrm{Al}-\mathrm{P})$ & -0.532 & 0.2832 \\
Fe-P vs. $\mathrm{K}$ & $\mathrm{K}=0.0362-0.00005(\mathrm{Fe}-\mathrm{P})$ & -0.608 & 0.3694 \\
Ca-P vs. $\mathrm{K}$ & $\mathrm{K}=0.0445-0.00005(\mathrm{Ca}-\mathrm{P})$ & -0.432 & 0.1867 \\
Al-P vs. $\mathrm{K}$ & $\mathrm{K}=0.0109+0.0067(\mathrm{Al}-\mathrm{P})$ & 0.3474 \\
Fe-P vs. $\mathrm{K}_{\mathrm{f}}$ & $\mathrm{Kf}=20.82-0.0338(\mathrm{Fe}-\mathrm{P})$ & 0.589 & 0.0093 \\
Ca-P vs. $\mathrm{K}_{\mathrm{f}}$ & $\mathrm{Kf}=9.58+0.0096(\mathrm{Ca}-\mathrm{P})$ & -0.497 & 0.4621 \\
Al-P vs. $\mathrm{K}_{\mathrm{f}}$ & $\mathrm{Kf}=0.6972+0.6214(\mathrm{Al}-\mathrm{P})$ & 0.096 & 0.3246 \\
Fe-P vs. $1 / \mathrm{n}$ & $1 / \mathrm{n}=0.6264+0.0009(\mathrm{Fe}-\mathrm{P})$ & 0.680 & 0.0144 \\
Ca-P vs. $1 / \mathrm{n}$ & $1 / \mathrm{n}=0.7244+0.0003 \mathrm{Ca}-\mathrm{P})$ & 0.570 & $0.4621-$ \\
Al-P vs. $1 / \mathrm{n}$ & $1 / \mathrm{n}=0.6972+0.6214(\mathrm{Al}-\mathrm{P})$ & 0.120 & 0.697 \\
\hline
\end{tabular}

$\mathrm{b}=$ Langmuir adsorption maximum; $\mathrm{K}=$ Langmuir constant related to bonding energy; $\mathrm{K}_{\mathrm{f}}($ intercept$)=$ Freundlich constant related to extent of adsorption; $1 / n=$ Slope of the Freundlich isotherm.

\subsection{Correlation between Langmuir and Freundlich Model Parameters and Selected Soil Properties}

\subsection{Phosphorus Adsorption}

Comparing the highest amount of $\mathrm{P}$ adsorbed in the five soils it was found that the soils have different $\mathrm{P}$ adsorbing capacities (Table 8). Differences in the adsorption capacity observed between the different soil types could be due to the differences in soil physical and chemical properties. The highest adsorption was found at the highest applied rate of $540 \mathrm{mg} \mathrm{P} \mathrm{kg}^{-1}$ soil. The higher and the least average $\mathrm{P}$ adsorbed observed from the experiment were on Shire Nitosols and Birki Fluvisols, respectively.

Table 8 Phosphorus adsorbed by different soils at 24 hours equilibration period

\begin{tabular}{|c|c|c|c|c|c|}
\hline \multirow[b]{2}{*}{ Applied P ( mg kg $\left.{ }^{-1}\right)$} & \multicolumn{5}{|c|}{ Phosphorus adsorbed $\left(\mathrm{mg} \mathrm{kg}^{-1}\right)$} \\
\hline & Brki Fluvisols & Agulae Cambisols & Wukro Vertisols & Wukro Arenosols & Shire Nitosols \\
\hline 60 & 49.13 & 50.16 & 56.54 & 54.38 & 59.08 \\
\hline 120 & 97.71 & 99.59 & 112.62 & 93.21 & 115.66 \\
\hline 180 & 131.46 & 146.59 & 169.32 & 134.87 & 173.20 \\
\hline 240 & 151.29 & 186.76 & 215.32 & 175.29 & 226.20 \\
\hline 300 & 184.63 & 220.79 & 270.87 & 219.96 & 276.99 \\
\hline 360 & 198.63 & 250.75 & 325.46 & 242.12 & 327.57 \\
\hline 420 & 211.21 & 274.09 & 365.71 & 275.12 & 377.44 \\
\hline 480 & 222.21 & 295.88 & 405.96 & 322.04 & 414.90 \\
\hline 540 & 224.62 & 310.02 & 454.96 & 345.62 & 456.44 \\
\hline Mean & 163.43 & 203.85 & 264.09 & 206.96 & 269.72 \\
\hline
\end{tabular}


At low initial $\mathrm{P}$ addition ( $60 \mathrm{mg} \mathrm{P} \mathrm{kg}^{-1}$ soil), percent of $\mathrm{P}$ adsorption was maximum while at high initial $\mathrm{P}$ addition (540 $\mathrm{mg} \mathrm{P} \mathrm{kg}^{-1}$ ), percent $\mathrm{P}$ adsorption was minimum. As increment of $\mathrm{P}$ addition, percent adsorption decreased. It can be concluded that soil P saturation can decrease adsorption, i.e. when the soil is saturated with $\mathrm{P}$, rate of adsorption decreased. This reduction in percent $\mathrm{P}$ adsorption could be due to increasing concentration of applied $P$ causing excess $\mathrm{P}$ on soil adsorption sites resulting in P release into solution. An inverse relationship between soil $\mathrm{P}$ saturation and adsorption was noticed by (45).

Linear Langmuir adsorption isotherm of the five soils showed different curves (Figure 3). The linear Freundlich adsorption isotherm curves also indicated differences among the soils (Figure 4). The Langmuir and Freundlich equations well fitted to the data on all the soils (Figures 3, 4 and Table 5 ). The two models showed similar curves for Wukro Vertisols and Shire Nitosols as well as for Agulae Cambisols and Wukro Arenosols among the soil types (Figures 3 and 6).Slope of the Freundlich model $(1 / n)$ is a measure of the heterogeneity of a system. A more homogeneous system will have $(1 / n)$ value approaching unity and a more heterogeneous system will have $1 / \mathrm{n}$ value approaching zero (49).

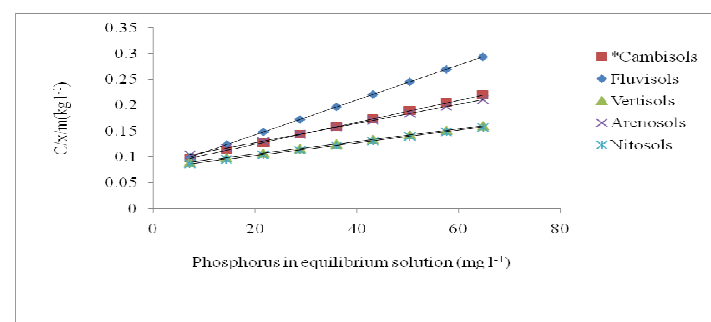

Figure 3. Isotherms for the adsorption of added P obtained using linear Langmuir model

$*=\mathrm{C} /(\mathrm{x} / \mathrm{m})=0.077551+0.00337(\mathrm{C})$ and $\mathrm{R}^{2}=0.97$, for Fluvisols; $\mathrm{C} / \mathrm{x} / \mathrm{m}=$ $0.082551+0.002121(\mathrm{C})$ and $\mathrm{R}^{2}=0.94$, for Cambisols; $\mathrm{C} / \mathrm{x} / \mathrm{m}=0.080935$ $+0.001219(\mathrm{C})$ and $\mathrm{R}^{2}=0.90$, for Vertisols; $\mathrm{C} / \mathrm{x} / \mathrm{m}=0.090021+0.00186(\mathrm{C})$ and $\mathrm{R}^{2}=0.88$, for Arenosols; $\mathrm{C} / \mathrm{x} / \mathrm{m}=0.077483+0.001234(\mathrm{C})$ and $\mathrm{R}^{2}=$ 0.96 , for Nitosols.

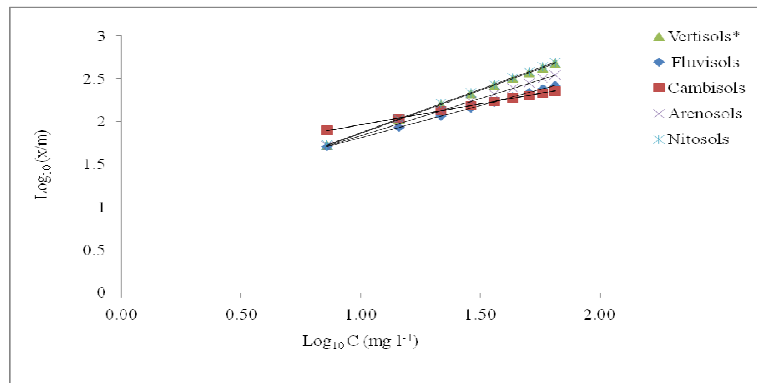

Figure 4. Isotherms for the adsorption of added P obtained using linear Freundlich model

$*=\log 10(\mathrm{x} / \mathrm{m})=1.0690+0.74072 \times \log 10(\mathrm{C})$ and $\mathrm{R}^{2}=0.97$, for Fluvisols; $\log 10(\mathrm{x} / \mathrm{m})=1.4793+0.48735 \times \log 10(\mathrm{C})$ and $\mathrm{R}^{2}=98$, for Cambisols; $\log 10(\mathrm{x} / \mathrm{m})=0.862582+1.00535 \times \log 10(\mathrm{C})$ and $\mathrm{R}^{2}=0.99$, for Vertisols; $\log 10(\mathrm{x} / \mathrm{m})=0.96916+0.87073 \times \log 10(\mathrm{C})$ and $\mathrm{R}^{2}=0.99$, for Arenosols; $\log 10(\mathrm{x} / \mathrm{m})=0.862043+1.01240 \times \log 10(\mathrm{C})$ and $\mathrm{R}^{2}=0.99$, for Nitosols.

Comparing the amount of $\mathrm{P}$ adsorbed in the five soils by estimating adsorbed $\mathrm{P}$ from Langmuir isotherm, it was observed that each soil has different capacities to adsorb $\mathrm{P}$ (168.69 -275.85 mg kg${ }^{-1}$ ). Similarly, P adsorption calculated from linear Freundlich adsorption isotherm showed differences in $\mathrm{P}$ adsorption of the soils with variations in magnitude from that of Langmuir (165.31 - $\left.274.44 \mathrm{mg} \mathrm{kg}^{-1}\right)$. Similarly, it was reported that phosphate adsorption in many soils can be described well by the Langmuir or Freundlich adsorption isotherms (51).

The Langmuir adsorption maximum (b) for the five soils ranged from $296.6 \mathrm{mg} \mathrm{P} \mathrm{kg}^{-1}$ soil for Birki Fluvisols to 820.4 $\mathrm{mg} \mathrm{P} \mathrm{kg}{ }^{-1}$ soil for Wukro Vertisols (Table 9). The adsorption maximum in the Wukro Vertisols may be due to relatively higher clay, $\mathrm{CaCO}_{3}$ and $\mathrm{Ca}-\mathrm{P}$ contents in the soil. The constant related to bonding energy $(\mathrm{K})$ was highest for Wukro Fluvisols $\left.\left[0.0447 \mathrm{~L}^{-1} \mathrm{mg}^{-1} \mathrm{P}\right)\right]$ and lowest for Wukro

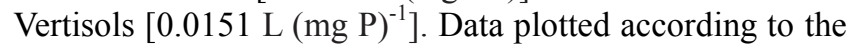
linear form of the Freundlich model indicated exponent $(1 / \mathrm{n})$ values of less than or equal to one in all the soils (Table 9).

Table 9. Adsorption parameters of the Langmuir and the Freundlich models for the soils

\begin{tabular}{|c|c|c|c|c|c|c|c|c|c|}
\hline \multirow[b]{2}{*}{ Soil type } & \multicolumn{5}{|c|}{ Langmuir parameters } & \multicolumn{4}{|c|}{ Freundlich parameters } \\
\hline & Slope $=(1 / b)$ & B (mg kg-1) & Y-intercept & Kb (mg kg-1) & $\begin{array}{l}K\left(\mathbf{L ~ m g}^{-1}\right. \\
\mathbf{P})\end{array}$ & $\begin{array}{c}\text { Y-intercept }= \\
\left(\log K_{f}\right)\end{array}$ & $\begin{array}{c}\mathbf{K}_{\mathbf{f}}(\mathbf{m g} \\
\left.\mathbf{k g}^{1}\right)\end{array}$ & $\begin{array}{c}\text { Slope }=(1 / \\
n)\end{array}$ & SPEC \\
\hline Fluvisols & 0.00337 & 296.6 & 0.0755 & 13.24 & 0.0447 & 1.0690 & 11.72 & 0.7467 & 2.10 \\
\hline Cambisols & 0.00212 & 471.6 & 0.0826 & 12.11 & 0.0257 & 1.4793 & 30.15 & 0.4874 & 9.82 \\
\hline Vertisols & 0.00122 & 820.4 & 0.0809 & 12.36 & 0.0151 & 0.8623 & 7.29 & 1.0053 & 0.72 \\
\hline Arenosols & 0.00181 & 537.5 & 0.0900 & 11.11 & 0.0207 & 0.9692 & 9.31 & 0.8707 & 1.25 \\
\hline Nitosols & 0.00123 & 810.5 & 0.0775 & 12.91 & 0.0159 & 0.8620 & 7.28 & 1.0124 & 0.701 \\
\hline
\end{tabular}

$\mathrm{b}=$ Langmuir adsorption maximum; $1 / \mathrm{b}=$ Slope of Langmuir model; $\mathrm{K}=$ Langmuir constant related to bonding energy; $\mathrm{K}_{\mathrm{f}}=$ Freundlich constant related to extent of adsorption; $1 / \mathrm{n}=$ Slope of the Freundlich isotherm and SPEC $=$ Solution P equilibrium concentration.

Similar results were reported by (50). According to them, Freundlich model is empirical in nature and implies that adsorption decreases exponentially with increasing saturation of exchange sites with P.It is obvious from Table 9 that Cambisols had minimum $(1 / \mathrm{n})$ value, i.e. 0.4874 while Nitosols has maximum $(1 / \mathrm{n})$ value, i.e. 1.0124 . Therefore, 
the Nitosols and Vertisols have relatively more homogeneous adsorption sites while Cambisols have more heterogeneous sites.

According to (52), $\mathrm{K}_{\mathrm{f}}$ is dependent on the solution concentration. (53) stated that $\mathrm{K}_{\mathrm{f}}$ is adsorption capacity while according to (54) it is extent of adsorption ( $\left.\mathrm{mg} \mathrm{kg}^{-1}\right)$.

According to (45), solution $\mathrm{P}$ concentration equilibrium with adsorbed $\mathrm{P}$ was calculated by dividing Freundlich $\mathrm{K}_{\mathrm{f}}$ by antilog of the Freundlich slope $\left[\mathrm{K}_{\mathrm{f}} / \operatorname{antilog}(1 / \mathrm{n})=\mathrm{SEPC}\right]$. The values of SEPC calculated using these formulae for soils are indicated in Table 9.

\section{Conclusions}

The results of the study depicted that both Langmuir and Freundlich adsorption models are robust in predicting $\mathrm{P}$ adsorption in the soils of the Region. The results of this study also revealed differences in $\mathrm{P}$ adsorption among the soils studied. Nitosols and Vertisols showed relatively higher $\mathrm{P}$ adsorption maxima compared to the other soils. The differences in the $\mathrm{P}$ adsorption capacities of the soils indicated that the use of blanket $\mathrm{P}$ fertilizer rate recommendations without studying optimum rate for each crop, used in the study area, may fail to increase yield in the areas as it may lead to under-application or over-application of P. Phosphorus adsorption characteristics were influenced by some soil properties. The results identified that soil properties like clay, sand, $\mathrm{CEC}$ and $\mathrm{CaCO}_{3}$ contents influence $\mathrm{P}$ adsorption in the study area. These further indicated that the properties of the different forms of soil $\mathrm{P}$ were in the order of Ca-P > Fe-P > Al-P in all the soils studied except in one soil. The result of this study could be used for further soil test based $\mathrm{P}$ fertilizer recommendations by considering the amount of $\mathrm{P}$ fixed in a growing season.

\section{Acknowledgment}

The authors express their appreciation to the Ethiopian Institute of Agricultural Research for funding the research work.

\section{References}

[1] G.M. Pierzynski, J.T. Sims and G.F., Vance. Soils and environmental quality. 3rd ed., Taylor and Francis, Boca Raton, USA. 2005.

[2] M.L. Leclerc M.C. Nolin, D. Cluis and R.R. Simard. Grouping soils of the Montreal lowlands (Quebec) according to fertility and $\mathrm{P}$ sorption and desorption characteristics. Can. J. Soil Sci., 81: 71-83. 2001.

[3] K. Daly, D. Jeffrey and H. Tunney. The effect of soil type on phosphorus sorption capacity and desorption dynamics in Irish grassland soils. Soil Use Manage, 17: 12-20. 2001.

[4] N.J. Barrow. Modeling the effects of $\mathrm{pH}$ on phosphate sorption by soils. J. Soil Sci., 35: 283-297. 1984.

[5] I. Bertrand, R.E. Holloway, R.D. Armstrong and M.J.
Mclaughlin. Chemical characteristics of phosphorus in alkaline soils from Southern Australia. Aust. J. Soil Res., 41: 61-76. 2003.

[6] O.A Amelidris and H. S. Ahmed. Phosphorus sorption capacity as a guide for phosphorus availability of selected Sudanese soil series. African Crop Science Journal, 20-65. 2012.

[7] H. Moazed Y. Hoseini, A. Naseri and F. Abbasi. Determining phosphorus adsorption isotherm in soil and its relation to soil characteristics. International Journal of Soil Science, 5 (3): 131-139. 2010.

[8] Z.A. Mohammad, S. Hoque and K.T. Osman. A comparison of the Langmuir, Freundlich and Temkin equations to describe phosphate sorption characteristics of some representative soils of Bangladesh. International Journal of Soil Science, 7: 91-99. 2012.

[9] L. Pulschen. Soils and Plant Nutrition Section, Terminal report for the period May 1983-April 1987. Agricultural Research Center, Debre Zeit, Ethiopia. 1987.

[10] Desta B. Diagnosis of phosphorus deficiency in Ethiopian soils. 18p. Soil Science Bulletin, No: 3. Institute of Agricultural Research, Addis Ababa, Ethiopia. 1952.

[11] Tekalign M. and I. Haque. Phosphorus status of some Ethiopian soils. I. Sorption characteristics. Plant and Soil, 102: 261-266. 1987.

[12] Fassil, K. and C. Yamoah. Soil fertility status and Numass fertilizer recommendation of Typic Hapluusterts in the nrthern highlands of Ethiopia. World Applied Sciences Journal, 6(11): 1473-1480. 2009.

[13] C. Behn, M. Janssen, G.A. Yalemsew and B. Lennartz. Phosphorus contents and phosphorous sorption in soils of the Gilgel Gibe catchment, SW Ethiopia. The Smithsonian/NASA Astrophysics Data System, Geophysical Research, Abstracts. 2013.

[14] Birru Y., Heluf G.. and V.P. Gupta. Phosphorus sorption characteristics of some soils of the north-western highlands of Ethiopia. Ethiopian Journal of Natural Resources (EJNR). 5(1): 1-16. 2003

[15] D. Miressa and W.P. Robarge. Soil characteristics and management effects on phosphorus sorption by highland plateau soils of Ethiopia. Soil Science Society of America Journal, 63(5): 1455-1462. 1999

[16] HTSL (Hunting Technical Service Limited). Tigray rural development study, Annex 4. Land and water resources consultants in association with Sir M. Macdonald and Partners, London, UK. 1976.

[17] G.W. Meijerin. Alternative cropping practices in Ethiopia: A literature review, PIMEA Working Paper 2002-2005, Wageningen University, the Netherlands. 2002.

[18] P.R. Day. Particle fractionation and particle-size analysis. pp. 545-567. In: Black, CA, D.D. Evans, J.L. Ensminger and F.E. Clark (eds). Methods of soil analysis. Part I. ASA, WI, Madison, USA. 1965.

[19] D.L. Rowell. Soil science: Method and applications. Longman Scientific and Technical, Longman Group UK Limited Addison, Wesley, England. 350p. 1994. 
[20] M. Peech. Hydrogen-ion activity. pp. 914-926. In: CA, Black, D.D. Evans, J.L. Ensminger and F.E. Clark (eds). Methods of soil analysis. Part II.ASA, WI, Madison, USA. 1965.

[21] H.D. Chapman. Cation exchange capacity. pp. 891-901. In: CA, Black, D.D. Evans, J.L. Ensminger and F.E. Clark (eds). Methods of soil analysis. Part II. ASA, WI, Madison, USA. 1965.

[22] P.R. Hesse. A text book of soil chemical analysis. Murray Publishers Limited, London, UK. 1971.

[23] FAO (Food and Agriculture Organization). The Euphrates Pilot Irrigation Project Methods of Soil analysis. Gadeb Soil laboratory (A laboratory Manual), Rome, Italy. 1974

[24] S.R. Olsen, C.V. Cole, L. Watanabe and A. Dean. Estimation of available $\mathrm{P}$ in soils by extraction with $\mathrm{NaHCO}_{3}$. USDA Cir 939, US Government Printing Office, Washington D. C., USA. 1954

[25] F.S. Watanabe and S.R. Olsen. Test of an ascorbic acid method for determining phosphorus in water and NaHCO3, extracts from soil. Soil Science Society of America Proceeding, 29:677-678. 1965.

[26] A. Walkley and C.A. Black. An examination of the method for determining soils organic matter and a proposed modification of the chromic acid titration method. Soil Science, 37: 29-38. 1934.

[27] S.C. Chang and M. L. Jackson. Fractionation of soil phosphorus. Soil Science, 84: 133-144. 1957.

[28] G.W. Peterson and R.B. Corey. A modified Chang and Jackson procedure for routine fractionation of inorganic soil phosphates. Soil Science Society of America Proceedings, 30: 563-565. 1966

[29] J. Murphy, and J.P. Riley. A modified single solution method for the determination of phosphate in natural waters. Analytica Chimica Acta, 27: 31-36. 1962.

[30] R.L. Fox. and E.J. Kamprath. Phosphate sorption isotherms for evaluating the phosphorous requirements of soils. Soil Sci. Soc. Am. Proc., 34: 902-907. 1970M. Ayaz, A. Saleem and M. Memon. Phosphorus adsorption parameters in relation to soil characteristics. Journal Chemical Society of Pakistan, $32: 129-139.2010$

[31] Charman P.E. and M.M. Roper. Soil organic matter. In: Charman P.E., Murphy B.W., eds. Soils-their properties and management, $3^{\text {rd }}$ edition. Melbourne, Australia: Oxford University Press, pp. 276-285. 2007.

[32] R.J. Shaw. Soil salinity-electrical conductivity and chloride In: Peverill K.I., Sparrow L.A., and Reuter D.J., eds. Soil Analysis: An Interpretation Manual. pp. 129-145. CSIRO Publishing, Collingwood, Australia. 1999.

[33] A.J. Metson. Methods of chemical analysis for soil survey samples. Newzealand Department of Scientific and Industrial Research, Soil Bureau Bulletin. pp. 168-175. In: Hazelton, P.A, Murphy, B.W., eds. Interpreting soil test results: what do all the, numbers mean?. $2^{\text {nd }}$ Edition. Government Printer,Wellington, New Zealand, New South Wales (NSW) Department of Natural Resources, CSIRO Publishing, Collingwood, Australia. 1961.

[34] F. Nachtergaele, H.V. Velthuizen, and L. Verelst. Harmonized world soil database. (version 1.1). FAO, Rome, Italy and Laxenburg, Austria.2009.
[35] J. Landon. Booker tropical soil manual: Handbook for soil survey and agricultural land evaluation in the tropics and subtropics. A John Wiley and Sons, New York. 1991.

[36] E.U. Onweremadu. Predicting phosphorus sorption characteristics in highly weathered soils of South-Eastern Nigeria. Research Journal of Environmental Sciences, 1: 47-55.2007.

[37] B. Singh and R.J. Gilkes. Phosphorus sorption in relation to soil properties for the major soil types of south-west Australia. Aust. J. Soil Res., 29: 602-618. 1991

[38] Y. Hoseini and R. D. Taleshmikaiel 2013. Comparison of phosphorus adsorption isotherms in soil and its relation to soil properties. International Journal of Agriculture, 3 (1): 163-171. 2013

[39] M. Ayaz, A. Saleem and M. Memon. Phosphorus adsorption parameters in relation to soil characteristics. Journal Chemical Society of Pakistan, 32 :129-139. 2010

[40] L. Zhuan-xi, Z. Bo, T. Jia-liang, and W. Tao. Ecological Engineering. pp 35-57. 2009.

[41] M. Arshed Rahmatulla M. Salim and M, Yousaf. Soil properties related to phosphorus sorption as described by modified Freundlich equations in some soils. International Journal of Agriculture and Biology, 4: 290-292. 2000.

[42] R. Burt., M.D. Mays, E.C. Benham and M.A. Wilson. Phosphorus characterization and correlation with properties of selected bench mark soil of the United States. Commun. Soil Sci. Plant Anal., 33: 117-142. 2002.

[43] S.K. Sanyal and S.K. De Datta. Chemistry of phosphorus transformations in soil. Adv. Soil Sci., 16: 1-120. 1991.

[44] ICRISAT (International Crops Research Institute for the Semi-Arid Tropics).. Farming Systems. Pp.255-259. In ICRISAT Annual Report 1984. ICRISAT, Patancheru, India. 1985.

[45] H. Amjad G. Abdul and M. Ghulam. Use of models for phosphorus adsorption on some sodic soils of Punjab. International Journal of Agriculture and Biology, 2: 241-248. 2006.

[46] N.A. Polyzopoulos, V.Z. Keramidas and H. Kiosse. Phosphate sorption by some Alfisols of Greece as described by commonly used isotherms. Soil Sci. Soc. Am. J., 49: 81-4. 1985.

[47] M. Del Bubba, C.A. Arias and H. Brix. Phosphorus adsorption maximum of sands for use as media in subsurface flow constructed reed beds as measured by the Langmuir isotherm. Water Res., 37: 390-400. 2003.

[48] M.S. Bakheit, and A. Pakermanjie. Phosphate adsorption and desorption by calcareous soils of Syria. Commun. Soil Sci. P1 Anal., 24: 197-210. 1993.

[49] T. Gregory, L. K. Chelsey and K. D. Shimizu. A critical examination of the use of the Freundlich isotherm in characterizing molecularly imprinted polymers (MIPS). Analytica Chemica Acta., 528: 107-113. 2005.

[50] R.G. McLaren and K.C. Cameron.. Soil Science: An introduction to the properties and management of New Zealand soils. Oxford University Press, Auckland- New Zealand. 1990 
[51] S. Shai laja. Phosphate adsorption-desorption in selected Vertisols. An MSc Thesis Presented to Andhra Pradesh Agricultural University. 1989.

[52] S. Kuo, and E.G., Lotse. Kinetics of phosphate adsorption and desorption by lake sediments. Soil Sci. Soc. Am. Proc., 38: 50-54. 1974.

[53] M. Zhou and Y. Li. Phosphorus-sorption characteristics of calcareous soils and limestone from the southern Everglades and adjacent farmlands. Soil Sci. Soc. Am. J., 65: 1404-12. 2001.

[54] G..S. Bahl and G.S. Toor. Influence of poultry manure on phosphate availability and the standard phosphate requirement of crop estimated from quantity-intensity relationships in different soils. Bioresource Tech., 85: 317-322. 2002. 